\title{
O DESEJO DO PSICANALISTA E SUA IMPLICAÇÃO NA TRANSFERÊNCIA SEGUNDO O ENSINO DE LACAN
}

\author{
Júlio Eduardo de Castro* \\ Ilka Franco Ferrari**
}

\section{Resumo}

Este artigo aborda a ética da psicanálise que é transmitida antes de tudo a partir da experiência intensiva, também chamada classicamente de a análise do psicanalista, principalmente por meio da investigação da expressão lacaniana desejo do psicanalista. Para tal, recorre ao ensino de Lacan, nitidamente no que diz respeito ao estatuto do sintoma na teoria e prática psicanalíticas e aos nomeados "operadores éticos do psicanalista". Do ensino de Lacan extraímos esses operadores clínicos da ética psicanalítica: o desejo do psicanalista; o discurso do psicanalista; o ato do psicanalista; o saber do psicanalista. Esses operadores cumprem a função de coordenadas teórico-conceituais a nos guiar durante a abordagem do mal-estar (e, mais especificamente, do sofrimento) proveniente do sintoma que leva um sujeito à busca pela psicanálise como modo e opçáo de tratamento. Da tomada/abordagem do sintoma no campo da ética da psicanálise retiramos consequências quanto ao agir/proceder do psicanalista na operacionalização dessa mesma ética a partir da situação clínica.

Palavras-chave: desejo do psicanalista; transferência; sintoma; psicanálise em intensão; ética da psicanálise.

\section{Abstract}

THE PSYCHOANALYST'S DESIRE AND HIS IMPLICATION IN THE TRANSFERENCE ACCORDING TO THE TEACHING OF LACAN

This article approaches the ethics of the psychoanalysis that is transmitted by intensive experience, also called the psychoanalyst's analysis, mainly through the investigation of the psychoanalyst's expression lacaniane psychoanalyst's desire.

* Universidade Federal de São João del Rei, São João del Rei, MG, Brasil.

** Pontifícia Universidade Católica de Minas Gerais, Belo Horizonte, MG, Brasil. 
In order to do that, it falls back upon Lacan's guideline mainly in what it comes to the rule of the symptom in the psychoanalytic theory and also the so called 'psychoanalyst's ethical operators'. From Lacan's teachings, we extract these clinical operators of the psychoanalytic ethics: the psychoanalyst's desire; the psychoanalyst's discourse; the psychoanalyst's acting; the psychoanalyst's knowledge. These operators fulfill the role of being the theoretical-conceptual and clinical guideline to guide us at the approach of the discomfort and suffering from the symptom that inexorably makes one to look for the psychoanalysis as a treatment. Concerning the symptom at the psychoanalysis ethics, we get consequences towards the acting of the psychoanalyst when operating this same ethics.

Keywords: psychoanalyst's desire; transfer; symptom; psychoanalysis intensive; ethics of the psychoanalysis.

\section{Resumen}

EL DESEO DEL PSICANALISTA Y SU IMPLICACIÓN EN LA TRANSFERENCIA SEGÚN LA ENSEÑANZA DE LACAN

Este artículo aborda la ética de la psicoanálisis que es transmitida antes de todo a partir de la experiencia intensiva, también llamada clásicamente del análisis del psicoanalista, principalmente por medio de la investigación de la expresión lacaniana deseo del psicoanalista. Para tal, recurre a la enseñanza de Lacan, nítidamente en lo que concierne al estatuto del síntoma en la teoría y práctica psicoanalíticas y a los nombrados "operadores éticos del psicoanalista". De la enseñanza de Lacan extraemos esos operadores clínicos de la ética psicoanalítica: el deseo del psicoanalista; el discurso del psicoanalista; el acto del psicoanalista; el saber del psicoanalista. Esos operadores cumplen la función de coordenadas teórico-conceptuales a guiarnos durante el abordaje del malestar (y, más específicamente, del sufrimiento) proveniente del síntoma que lleva un sujeto a la búsqueda por la psicoanálisis como modo y opción de tratamiento. De la toma/abordaje del síntoma en el campo de la ética de la psicoanálisis, retiramos consecuencias en cuanto al actuar/proceder del psicoanalista en la operacionalización de esa misma ética a partir de la situación clínica.

Palabras clave: deseo del psicoanalista; transferencia; síntoma; psicoanálisis en intensión; ética de la psicoanálisis.

\section{O desejo do psicanalista e sua implicação na transferência}

A expressão desejo do psicanalista teve sua primeira aparição no ensino de Lacan no Seminário 6, dedicado ao desejo e sua interpretação (Lacan, 1958-1959/ 
[s.d.]), mais especificamente na lição 27, de 01/07/1959. Tal referência surge em uma situação de ensino na qual Lacan póe, frente a frente, o desejo como desejo do Outro e o desejo do psicanalista, isso num contexto teórico e clínico em que buscava resposta para o fundamento da posição do psicanalista.

Nas palavras de Lacan à época, "o problema da análise é o desejo que o sujeito tem por reencontrar, que é este desejo do Outro, nosso desejo, este desejo que está presente somente no que o sujeito supóe que o demandamos" (Lacan, 1958-1959/[s.d.], lição 27 de 01/07/1959). E essa situação, segundo ele, só pode ser sustentada por meio da

manutenção de um artifício que faz parte de toda a regra analítica [...]. O essencial da análise dessa situação em que nos encontramos é ser o analista aquele que se oferece como suporte para todas as demandas e que não responde a nenhuma (Lacan, 1958-1959/ [s.d.], lição 27, de 01/07/1959).

Na sequência desse Seminário, Lacan relembra aos presentes que há um fator que jamais deve ser desconsiderado pelos psicanalistas, qual seja, a essência vazia do desejo, que supóe que o psicanalista nada deve desejar para o psicanalisando, não impondo assim a ele qualquer ideal de civilizabilidade, de curabilidade ou mesmo de normalidade subjetiva. Assim procedendo, ou seja, contendo a influência sugestiva de seus próprios ideais (subentendam-se preconceitos) na condução do processo psicanalítico, o psicanalista deixa o campo livre, porque vazio de respostas às demandas, para o desejo do sujeito-psicanalisante deslizar pela cadeia significante (associaçáo de ideias) e, desse modo, realizar-se como caminho a ser feito. Por isso Lacan assinala, entáo, para algo além do desejo do Outro, para a vacuidade constitutiva do desejo como a verdadeira mola ética que sustenta a regra fundamental da psicanálise e que, por decorrência, move o processo psicanalítico.

A citação acima, além de vir acompanhada da articulação do desejo como falta-a-ser, característica marcante da política do psicanalista (Lacan, 1961/1998, p. 591-652), curiosamente é seguida por várias linhas dedicadas ao corte temporal como modo de o psicanalista, em posição de objeto, intervir apontando o vazio (e sua falta constitutiva) e, assim, manter aberta a perspectiva do desejo. Para Lacan, o desejo do psicanalista deve se limitar ao vazio, ao lugar que se deixa para o desejo do psicanalisando, de modo que ali situe o corte, por ele considerado o método mais eficaz de intervenção e interpretação psicanalítica.

É um dos métodos mais eficazes de nossa intervenção, é também um dos que deveremos usar mais. Mas neste corte há algo, esta mesma coisa que 
temos aprendido a reconhecer sob a forma de objeto fálico latente em toda relação de demanda, como significante do desejo (Lacan, 1958-1959/ [s.d.], liçáo 27, de 01/07/1959).

\section{Desejo advertido}

As ênfases dadas ao desejo, sempre fundado na falta, e ao corte, como modo de apontá-la na relação com o desejo do Outro, compóem o ponto/eixo denominado por Lacan de desejo do psicanalista. É em torno desse desejo que Lacan (1959-1960/1988) estabelece algumas coordenadas éticas da psicanálise no Seminário 7, e o localiza para-além do desejo do Outro, caracterizando-o, inclusive, como advertido. O desejo do psicanalista é, assim, diferentemente do desejo do Outro, desejo advertido, já que pressupóe para o psicanalista a posição de objeto da transferência.

Que se pode dizer, contudo, do emprego desse adjetivo, advertido, para caracterizar o desejo do psicanalista? Certamente tal desejo deve ser entendido como o que restou/resultou da destituição subjetiva promovida pela psicanálise em intensão. É possível, ainda, pensá-lo como advertido porque atravessado pelos enganos e desenganos vividos na situação de transferência através de seu pivô, o sujeito suposto saber.

A formaçáo do psicanalista exige que ele saiba, no processo em que conduz seu paciente, em torno do quê o movimento gira. Ele deve saber, a ele deve ser transmitido, e numa experiência, aquilo de que ele retorna. Esse ponto-eixo é o que eu designo - de um modo que, penso, lhes parece já suficientemente motivado, mas que, espero, à medida do nosso progresso, lhes parecerá cada vez mais claro, cada vez mais necessário -, é o que designo pelo nome de desejo do psicanalista (Lacan, 1964/1979, p. 218-219).

O desejo do psicanalista é no ensino de Lacan inicialmente situado como um ponto-pivô, ponto-eixo em torno do qual deve girar a ética da psicanálise.

Já no Seminário 12 Lacan (1964-1965/[s.d.]), referindo-se à identificação, faz um longo percurso para contrapô-la ao desejo do psicanalista. E o contexto do qual se serve para realizar tal contraposição é o tratamento psicanalítico. Lacan, nessa época, estava envolvido em denunciar os desvios da prática psicanalítica, principalmente os desvios que se sustentavam na premissa de que o psicanalista 
deveria ser um suporte identificatório para os seus psicanalisandos. Oferecer-se como Ideal ao eu do psicanalisando era, então, o lema de uma prática que ficou conhecida como "Psicologia do Eu", que sustentava o que deveria ser o final de todo e qualquer tratamento psicanalítico: a identificação do psicanalisando ao psicanalista. Contrapondo-se a essa concepção de final de análise, Lacan construiu suas formulaçóes sobre o desejo do psicanalista.

Reler a pulsão freudiana como um conceito fundamental da psicanálise, desvinculando-a de vez de qualquer leitura biologizante (Lacan, 1964/1998), fez parte da estratégia lacaniana na denúncia desses desvios. Isso porque a Psicologia do Eu propunha a existência de um tipo de amor, chamado de genital, pressuposto ao conceito de pulsão genital. Lacan considerava que a concepçáo de levar o sujeito em análise ao amor genital - para tal servindo-se da identificação ao eu forte do psicanalista - exigia a retomada dos princípios éticos freudianos. Princípios que deveriam nortear a ação do psicanalista e que acabaram levando-o à criação do desejo do psicanalista, que faria, a partir de então, oposição a todo e qualquer tratamento ancorado na identificação.

Afirmando que "o desejo vem do Outro, e o gozo está do lado da Coisa", Lacan (1964/1998, p. 867) se pergunta qual seria a finalidade, nas análises, do desejo do psicanalista, para além da terapêutica. Em suas palavras, é impossível não distingui-la da terapêutica quando se trata de produzir um psicanalista, pois, "como dissemos sem entrar na mola da transferência, é o desejo do analista que, em última instância, opera na psicanálise” (Lacan, 1964/1998, p. 868).

No Seminário 7 Lacan (1959-1960/1988, p. 360) também se perguntava sobre o que seria o desejo do psicanalista. Fez a opção, nesse momento, de abordá-lo pelo que ele não é, já que se trata de desejo que não pode desejar o impossível. Formula-o para além da demanda de felicidade e de qualquer promessa e assegura que o que o analista tem a dar, diferentemente do parceiro amoroso, é o que ele tem, ou seja, seu desejo prevenido/advertido. O último capítulo desse mesmo Seminário de Lacan (1959-1960/1988, p. 373-390) é dedicado a trabalhar os paradoxos da ética, e nele aparece a pergunta ética da psicanálise: "Agiste em conformidade com teu desejo?”. Para chegar a tal formulação, foi indispensável recorrer ao conceito de pulsão (e sua satisfação), bem como a afirmação de que a psicanálise não deve trabalhar a favor do serviço dos bens ${ }^{1}$ e de sua racionalizaçáo moralizante. Contrariamente a esse serviço, a ética da psicanálise se aproxima, por sua vez, da experiência trágica da vida, pois é na "dimensão trágica que as açôes se inscrevem, e que somos solicitados a nos orientar em relação aos valores” (Lacan, 1959-1960/1988, p. 376).

A dimensão trágica da experiência psicanalítica é, portanto, outro elemento que serve de contraponto ao serviço dos bens e à finalidade terapêutica da psica- 
nálise. E é por meio do desejo do psicanalista - em sua contiguidade à experiência trágica da vida - que haveria chance de uma ética sustentada no desejo (do Outro e para além dele), e não em qualquer promessa ou ideal de felicidade, de cura ou de bem-estar.

\section{Desejo do psicanalista e agalma}

É no Seminário 8 (Lacan, 1960-1961/1992), dedicado à transferência, entretanto, que são encontradas inúmeras referências ao desejo do psicanalista. E todas elas são formuladas para manifestar a aversão de Lacan à relação diádica (ou interpessoal) na abordagem da transferência. Ele já havia lembrado aos seus leitores que o psicanalista deve pagar algo para cumprir sua função: com palavras, na interpretação e com sua pessoa (Lacan, 1961/1998, p. 593), já que "pela transferência ele é literalmente despossuído dela” (Lacan, 1959-1960/1988, p. 349).

Ao focalizar a atopia de Sócrates no mundo grego - o fato de ser Sócrates tão insituável, inclassificável quanto deveria ser o psicanalista -, Lacan examina a complexidade da transferência, localizando-a para além do psicanalisando. Para tal, uma vez mais recorre ao desejo do psicanalista no Seminário sobre a transferência, no momento em que se refere à atopia de Eros e de Sócrates, Lacan afirma que "Náo basta falar agora de katarsis, purificação do grosso do inconsciente no analista, porque isso é muito vago" (Lacan, 1960-1961/1992, p.108) e que havia analistas que, há muito tempo, já não se contentavam com isso. O importante, para ele, isto sim, é o que deve ser obtido de alguém para que ele possa ser um psicanalista. Naquela época costumava-se ouvir que o analista precisaria saber um pouquinho mais da dialética de seu inconsciente. E Lacan prossegue ao questionar: "Mas o que sabe ele disso exatamente, afinal? E, principalmente, até onde o que ele sabe disso precisou ir, com relação aos próprios efeitos do saber?” (Lacan, 1960-1961/1992, p.108). Para ele, a pergunta fundamental sobre o que deveria ser obtido para se dizer que ali havia um analista era relacionada ao que restava de suas fantasias e, mais ainda:

Sabem que sou capaz de ir mais longe e de dizer sua fantasia, se é que existe uma fantasia fundamental. Se a castração é aquilo que se deve aceitar no último termo da análise, qual deve ser, então, o papel da cicatriz da castração no érôs do analista? (Lacan, 1960-1961/1992, p. 108-109).

A esta questão Lacan responde que, para ele, tratava-se mesmo era de tentar articular e situar o que deve ser, ou do que fundamentalmente é o desejo do 
psicanalista. Isso a partir da topologia que já havia esboçado pelas coordenadas do desejo, já que as balizas idôneas da época passavam pela fenomenologia elaborada às voltas do tema, "pois o desejo do analista não é tal que possa se bastar pela referência diádica. Não é a relação com o paciente que pode, por uma série de eliminaçóes e excursóes, nos dar a chave. Trata-se de algo mais intrapessoal" (Lacan, 1960-1961/1992, p. 109). Nesse momento, ele faz questão de alertar que tal posição não implica que o psicanalista deva ser um Sócrates, um puro ou um santo, ainda que esses "exploradores" possam dar indicaçóes relativas ao campo em questão. Por meio deles, talvez seja possível definir,

em termos de latitude e de longitude, as coordenadas que o analista deve ser capaz de atingir para, simplesmente, ocupar o lugar que é o seu, o qual se define como aquele que ele deve oferecer vago ao desejo do paciente para que se realize como desejo do Outro (Lacan, 1960-1961/1992, p. 109).

E é justamente o desejo como desejo do Outro que se desdobra na transferência, na forma de amor, durante o percurso analítico: o sujeito passa da posição de érôménos (sujeito amado) à posição de érastès (objeto amante), na chamada metáfora do amor, segundo Lacan - que não vê nessa passagem nenhuma contraindicação, já que faz parte, desde o começo das análises, do chamado amor de transferência. A contraindicação está localizada, pelo contrário, do lado do psicanalista, nitidamente quando este lança seu próprio agalma sobre o psicanalisando.

[...], basta supor que o analista, mesmo à sua revelia, coloque por um instante seu próprio objeto parcial, seu agalma, no paciente com quem está lidando. Aí, com efeito, se pode falar de uma contraindicação (sic), mas, como veem, nada menos que localizável - ao menos enquanto a situação do desejo do analista não é explicitada (Lacan, 1960-1961/1992, p. 195).

Com efeito, Lacan reafirma - usando a palavra agalma para se referir à face brilhante do objeto $a-$ a importância de o psicanalista não projetar sobre o psicanalisando tal objeto, causa de seu próprio desejo. Isso seria reger a análise segundo os ideais do Outro [I(A)], o que estimularia, por conseguinte, a identificação ao psicanalista. Uma vez mais surge aqui a preocupação de Lacan com as análises dirigidas pelo serviço dos bens e com a identificação (cultural e subjetiva) aí promovida. 


\section{Desejo do psicanalista, angústia e identificaçáo}

As relações estreitas entre identificação e angústia são por Lacan (19611962/[s.d.]) examinadas desde o Seminário 9, dedicado à identificação. Nele, a angústia é tida como efeito da presença do objeto $a$ no campo do Outro, presença que abala, faz tremer as identificaçóes do sujeito aos ideais do Outro/eu. A via identificatória como meio para chegar ao final de análise é, portanto, tida por Lacan como um dos mais sérios desvios da psicanálise. Ao examinar as relaçóes da identificação com o desejo, principalmente nas psicoses, ele diz:

É certo que o psicótico não espera o analista para conhecer a angústia, é certo também que para todo sujeito a relação analítica é nesse domínio um terreno privilegiado. A angústia tem relaçóes estreitas com a identificação. Se na identificação se trata de algo que sucede no nível do desejo do sujeito em sua relação ao desejo do Outro, na psicose evidencia-se a maior fonte de angústia no fato de que o Outro é alguém cujo desejo mais profundo é não desejar, alguém que, por isso mesmo, se permite todas as projeçôes possíveis, as desvela também em sua subjetividade fantasmática. Ao ser assim, obriga o sujeito a colocar-se periodicamente a questão do que é o desejo do psicanalista, desejo sempre presumido, jamais definido, e podendo, na psicose e a todo instante, devenir desse lugar do Outro, de onde surge para o analisante a angústia (Lacan, 1961-1962/[s.d.], lição 18, de $02 / 05 / 1962$.

Deduz-se daí que, na direção do tratamento, a identificação é uma via cômoda, na verdade uma defesa contra a angústia, à qual o psicanalista deve se opor. E, mais ainda, que a angústia tem com o desejo do psicanalista uma grande proximidade topológica, proximidade essa marcada pela "presença do objeto $a$ no campo do Outro".

Ceder à identificação ao eu forte do psicanalista como meio de finalização do tratamento seria ainda para Lacan (1962-1963/2005, p. 142-143), no Seminário dedicado à angústia, deixar o objeto $a$ absolutamente intacto, intocável. Seria domar a transferência através da identificação sem, contudo, promover a sua destituição, ou seja, a destituiçáo/desengano do sujeito suposto saber. Todavia, o posicionamento de Lacan diante dessa teoria sobre um final de análise sustentado na identificação ao psicanalista nos diz que, pelo contrário, a análise deve, antes de tudo, fazer tremer os semblantes identificatórios, jamais reforçá-los. Para ele, "o que faz de uma psicanálise uma aventura singular é a busca do 
agalma no campo do Outro" (Lacan, 1962-1963/2005, p. 366). Lacan diz haver interrogado seus pares, diversas vezes, sobre o que convinha chamar de desejo do psicanalista, para que fosse "possível um trabalho analítico que tentasse levar as coisas além do limite da angústia” (Lacan, 1962-1963/2005, p. 366). E daí, considerou que "convém que o analista seja aquele que, minimamente, não importa por qual vertente, por qual borda, tenha feito seu desejo entrar suficientemente nesse $a$ irredutível para oferecer à questáo do conceito da angústia uma garantia real" (Lacan, 1962-1963/2005, p. 366). Com essas palavras - amparadas na localização topológica da angústia entre o desejo e o gozo - Lacan encerra o referido Seminário.

\section{Desejo do psicanalista e os conceitos fundamentais da psicanálise}

O Seminário 11 (Lacan, 1964/1979) é marcado por várias formulações sobre o desejo do psicanalista "como lugar de junção do campo da demanda, onde se presentificam as síncopes do inconsciente, com a realidade sexual" (Lacan, 1964/1979, p. 149). Uma vez mais Lacan se interroga sobre o que deve ser o desejo do psicanalista, para que ele opere de modo correto. Considera que essa questão é crucial e deixada de lado nas ciências modernas, a exemplo da física, em que ninguém se pergunta sobre o que é o desejo do físico. A própria formação do psicanalista, por sua vez, coloca no centro da questáo o desejo. Referindo-se ao que chamavam na época de análise didática, comenta: " $\mathrm{E}$ a análise didática não pode servir para outra coisa senão para levá-lo a esse ponto que designo em minha álgebra como o desejo do analista" (Lacan, 1964/1979, p. 17).

Além de assegurar que o desejo do psicanalista surge como uma incidência essencial e única do desejo no campo da ciência moderna, nesse mesmo Seminário Lacan se pergunta onde fica o ponto de disjunção e de conjugação, de uniáo e de fronteira entre a ciência moderna e a psicanálise, ponto que só pode ser ocupado pelo desejo do psicanalista. E para responder tal pergunta recorre, uma vez mais, ao conceito de pulsão, mais especificamente ao que ele próprio nomeou, a partir de Freud, de desmontagem da pulsão (Lacan, 1964/1979, p. 153). Sua aposta é que o conceito freudiano de pulsão abriu a perspectiva para que fosse formulado o desejo e, mais especificamente, o do psicanalista.

O desejo do analista não é um desejo puro. É um desejo de obter a diferença absoluta, aquela que intervém quando, confrontado com o significante 
primordial, o sujeito vem, pela primeira vez, à posição de se assujeitar a ele. Só aí pode surgir a significação de um amor sem limite, porque fora dos limites da lei, somente onde ele pode viver (Lacan, 1964/1979, p. 260).

Nesse Seminário dedicado aos quatro conceitos fundamentais da psicanálise, Lacan destaca principalmente a produção do "significante primordial" nas análises - a ser chamado posteriormente, no Seminário 17 (Lacan, 19691970/1992), de significante-mestre $\left(S_{1}\right)$ - e o objeto a como fundamento do "amor sem limite". Objeto em junção/continuidade com o campo do Outro e em disjunção/descontinuidade com o campo do gozo. Ao focalizar cada um dos quatro conceitos fundamentais da psicanálise, Lacan diz, insistentemente, da importância do desejo e da transferência (como demanda de amor dirigida ao psicanalista) naquilo que concerne à funçáo essencial do desejo do psicanalista. Isso porque, "enquanto o analista é suposto saber, ele é suposto saber também partir ao encontro do desejo inconsciente" (Lacan, 1964/1979, p. 222). E isso o levou a dizer

que o desejo é o eixo, o pivô, o cabo, o martelo, graças ao qual se aplica o elemento força, a inércia, que há por trás do que se formula primeiro, no discurso do paciente, como demanda, isto é, a transferência. O eixo, o ponto comum desse duplo machado, é o desejo do analista, que eu designo aqui como uma função essencial (Lacan, 1964/1979, p. 222).

Após designar o desejo do psicanalista como a função essencial na direção do tratamento, de forma enfática ele ainda assegura: "E não me digam que, esse desejo, eu não o nomeio, pois é precisamente um ponto que só é articulável pela relação do desejo ao desejo. Essa relação é interna. O desejo do homem é o desejo do Outro" (Lacan, 1964/1979, p. 222-223).

Transferência e engano são os termos articulados por Lacan ao se referir, nesse mesmo Seminário, ao desejo do psicanalista e a sua importância capital na direção do tratamento. Na verdade ele retoma aí (Lacan, 1964/1979, p. 239-241) o paradoxo da transferência já presente desde Freud: como meio (amistosidade em colaborar com a execução da regra fundamental) e como obstáculo (resistência). Ao dizer que a transferência não é, por sua natureza, a sombra de algo vivido antigamente, de antigas tapeaçóes do amor, pois nada poderia ser atingido in absentia, in effigie, reafirma: "o sujeito enquanto assujeitado ao desejo do analista deseja enganá-lo dessa sujeição, fazendo-se amar por ele, propondo por si mesmo essa falsidade essencial que é o amor" (Lacan, 1964/1979, p. 240). O efeito de 
transferência é visto então como efeito de tapeação "no que ele se repete presentemente aqui e agora. Ele só é repetição do que se passou assim-assim, por ter a mesma forma” (Lacan, 1964/1979, p. 240). O que lhe assegura dizer que o laço do desejo do psicanalista com o desejo do paciente é o que subjaz no amor de transferência. "É o que Freud traduziu numa espécie de rápido escamoteamento, um chamariz, dizendo - depois de tudo, é apenas o desejo do paciente - coisa para serenar os confrades" (Lacan, 1964/1979, p. 240). Isso porque, se é desejo do paciente, assim o é em seu encontro com o desejo do psicanalista, expresso por Lacan da seguinte maneira: "Esse desejo do analista, não direi de modo algum que não o nomeei ainda, pois como nomear um desejo? Um desejo, o cercamos. Muitas coisas na história nos dão aqui traço e pista” (Lacan, 1964/1979, p. 240).

Convém, nesse momento, recordar do artigo escrito por Lacan em 1967 (Lacan, 1968/2003a, p. 329-349), dedicado ao "engano do sujeito suposto saber”. Esse artigo é, na verdade, uma continuação do raciocínio presente na seção intitulada "Da interpretação à transferência", presente no Seminário 11 (Lacan, 1964/1979, p. 231-245). Enganar-se e desenganar-se segundo seu ensino são as duas faces da transferência. A primeira face (articulada ao sintoma analítico) possibilita a entrada em análise e a segunda anuncia sua finalização. Enganar-se e desenganar-se, portanto, são verbos que nos dizem do direito e do avesso da transferência.

Outras referências, dignas de nota e presentes no Seminário 11, assinalam, uma vez mais, a antinomia desejo-interpretação e desejo-idealização. Em uma delas, Lacan escreve o que chamou de fórmulas-referência:

se a transferência é o que, da pulsão, desvia a demanda, o desejo do analista é aquilo que a traz ali de volta. E, por essa via, ele isola o objeto $a$, o póe à maior distância do I (ideal) que ele, o analista, é chamado pelo sujeito a encarnar. É dessa idealização que o analista tem que tombar para ser o suporte do a separador, na medida em que seu desejo lhe permite, numa hipótese às avessas, encarnar, ele, o hipnotizado (Lacan, 1964/1979, p. 258).

Em outra fórmula, Lacan diz que o esquema que deixa como guia, de experiência e de leitura, "indica que a transferência se exerce no sentido de reconduzir a demanda à identificação" (Lacan, 1964/1979, p. 259), pois é na medida em que o desejo do psicanalista tende para um sentido contrário ao da identificação "que a travessia do plano da identificação é possível, pelo intermédio da separação do sujeito na experiência. A experiência do sujeito é assim reconduzida ao plano onde se pode presentificar, da realidade do inconsciente, a pulsão” 
(Lacan, 1964/1979, p. 259). Reencontrar a lógica pulsional no final de análise, mais especificamente a demanda de satisfação inerente à pulsão, é, para Lacan, a decorrência lógica da separação sujeito/objeto promovida pelo processo psicanalítico. Nesse processo, a extração do objeto $a$ do campo do Outro é necessária para que o psicanalista não ceda à demanda de ser suporte identificatório para o psicanalisando. Pelo contrário, é pelo fato de o psicanalista declinar desse lugar do ideal $[\mathrm{I}(\mathrm{A})]$ que o psicanalisante é forçado a ter de se haver com o seu ser-de-objeto, ser que, partindo da fonte, circula o objeto e a ela retorna, nos moldes do circuito da pulsão.

Aqui observamos que, se as principais referências de Lacan ao desejo do psicanalista são ainda incipientes nos Seminários 6 e 7, nos Seminários seguintes até o Seminário 12 elas são abundantes, com ápice, sem dúvida, no Seminário 11. Nesse Seminário, tais referências perpassam a abordagem de todos os quatro conceitos fundamentais da psicanálise (inconsciente, pulsão, repetição e transferência).

\section{Ética e desejo do psicanalista}

As relações do desejo com a identificação são examinadas por Lacan principalmente no Seminário 9, dedicado à identificação (Lacan, 1961-1962/ [s.d.]). Lacan considerou as coordenadas já estabelecidas por Freud, ou seja, que entre esses dois conceitos há uma área de interseção e, antes de tudo, a tendência à subordinação radical da identificação ao desejo do Outro e a seus ideais (I[A]). E essa tendência, ancorada no nome próprio herdado com o qual o sujeito se identifica, caminha na direção contrária à destituição subjetiva decorrente do processo analítico. De modo que, se por um lado o sujeito apoia sua formação nas identificaçóes aos ideais do Outro, por outro a destituição subjetiva implica na queda de algumas identificaçóes secundárias $\left(S_{2}\right)$ e no abalo ou tremor das identificações primárias $\left(S_{1}\right)$, dentre elas a identificação ao nome e corpo próprios. Com Freud, Lacan ainda aprendeu que a identificação, enquanto sustentada nos registros Imaginário e Simbólico, só ocorre em função de uma perda no Real. A extração do objeto $a$ do campo do Outro abriu para Lacan não somente a perspectiva da causa do desejo, como também, por decorrência, à análise da identificação, de seu mecanismo de funcionamento. Por isso Lacan, também no Seminário 12 (Lacan, 1964-1965), diz que o desejo do psicanalista precisa ser diferenciado topologicamente da identificação. E essa diferenciação não é sem importância, pois nos traria a marca de duas con- 
cepçóes distintas daquilo que se nomeia como final de análise: o final de análise sustentado na identificação ao eu forte do psicanalista; e o final de análise sustentado na destituição da transferência, ou seja, na transformação do sujeito suposto saber em dejeto, operação essa decorrente da extração do objeto a do campo do Outro. No primeiro caso, há a manutenção intacta da neurose de transferência, o que levou Lacan a dizer que "a neurose de transferência é a neurose do psicanalista. Se refugia na transferência na medida em que não se está no ponto quanto ao desejo do psicanalista" (Lacan, 1964-1965/[s.d.], lição 8, de 03/02/1965).

$\mathrm{O}$ risco de o psicanalista compactuar com a neurose de transferência culminaria inevitavelmente naquilo que se chamou de análise interminável ou sem fim. Por isso, a neurose de transferência "é imbatível justamente porque, não havendo solução para ela, a astúcia do condutor do jogo - se o analista merece seu nome - não pode ser mais que isto: de fazer culminar dela, de depreender dessa defesa, uma forma sempre mais pura” (Lacan, 1964-1965/[s.d.], lição 16, de 19/05/1965). O desejo do psicanalista, nessa operação, é o de "levar o sujeito a seu fantasma fundamental, e isso não é ensinar-lhe nada, é aprender com ele como fazê-lo" (Lacan, 1964-1965/[s.d.], lição 16, de 19/05/1965). É o psicanalisante que porta o saber fazer com o objeto $a$ em sua junção e disjunção ao sujeito $(\$ \triangleright \alpha)$, e o psicanalista está no lugar do resultado, na medida em que o favorece. Lacan se pergunta sobre qual deve ser o desejo do psicanalista para sustentar-se nesse ponto de suprema cumplicidade, e sempre aberto à surpresa. E, ao afirmar que o inesperado não é o risco, se pergunta:

Que é o inesperado senão o que se revela como espera já esperada, mas só quando chega? $\mathrm{O}$ inesperado atravessa o campo do esperado ao redor desse jogo da espera - e é fazendo frente à angústia ao redor do campo da espera, como Freud, nos textos fundamentais sobre esse tema já havia formulado (Lacan, 1964-1965/[s.d.], lição 16, de 19/05/1965).

Daí se conclui que o inesperado já esperado, porém ainda não vivido pelo sujeito, é, no contexto da vida, a morte e, no contexto da cura, o ato de finalização do tratamento psicanalítico. Quando o sujeito chega ao final de análise, principalmente por não se refugiar na identificação ao psicanalista, além de ter de se haver com o incurável de seu sintoma tem de se haver com os enganos que ali o levaram, dentre eles o engano do sujeito suposto ao saber.

Portanto, duas posiçóes opostas estão demarcadas por Lacan quanto ao final de análise: 1- a do refúgio na transferência, em que o sujeito suposto saber 
é mantido intacto e, exatamente por isso, a transferência e o tratamento permanecem sem fim; 2- a da destituição da transferência e do desengano do sujeito suposto saber como efeitos inevitáveis da redução do psicanalista à função de dejeto.

Alinhados a Lacan, outros autores (Albuquerque, 2012; Andrade Júnior, 2008; Castro, 2006; Cottet, 1982/1990 e Harari, 2012) também localizam o desejo do psicanalista no campo da ética da psicanálise, principalmente ao lerem essa expressão como um orientador clínico indispensável ao manejo da transferência ou seja, da prática psicanalítica - e, consequentemente, à direção do tratamento.

\section{Desejo e ato do psicanalista}

No Seminário dedicado ao ato do psicanalista (Lacan, 1967-1968/1995) há a afirmação categórica de que, no final da análise, o sujeito suposto saber, função que está no começo da lógica analítica, fica reduzido ao “"não estar/ser aî" que é o que é característico do próprio inconsciente, e que esta descoberta faz parte da mesma operação verdade" (Lacan, 1967-1968/1995, p. 90-91). A redução do psicanalista à condição de resto ou resíduo da operação analítica, à condição de objeto $a$, viria acompanhada da transformação do sujeito suposto saber em significante que falta ao Outro $[\mathrm{S}(\mathbb{A})]$. Por meio do desejo do psicanalista, como leme a dirigir a cura, o Outro é desvanecido e de seu campo é extraído o objeto a. O "não estar/ser aî" do psicanalista - uma vez que este já esteja desapossado da condição agalmática e, por isso mesmo, seja como tal tomado como lixeira - mostrou a Lacan que, tanto quanto o objeto $a$, o ser do psicanalista é ser sem essência. Entretanto, esse ser sem essência é o que, no lugar de causa, pôs em movimento o processo analítico $(a \rightarrow \$)$, e que agora, enquanto resto projetado sobre o psicanalista, aponta para a sua finalização.

Com esse argumento Lacan aproxima o desejo do psicanalista do ato do psicanalista. Além do ato do psicanalista produzir um psicanalista - e mais ainda pelo fato do sujeito suposto saber não ser um sujeito que esteja no ato, principalmente o de finalização ${ }^{2}$-, Lacan usa a expressão sujeito do ato para se referir à passagem de psicanalisante a psicanalista. Segundo ele, os objetos $a$,

Objetos sem essência que são, ou não, reevocados no ato a partir dessa espécie de sujeito que, como veremos, é o sujeito do ato; diria, uma vez que, como sujeito suposto saber, é um sujeito que não está no ato, ao final da experiência analítica (Lacan, 1967-1968/1995, p. 91). 
Portanto, o desejo do psicanalista - expressão esta que, como vimos, foi usada por Lacan anteriormente - passa, com o estatuto do ato, à condiçáo de coordenada marcante do final de análise. O objeto a está, portanto, no início do ato do psicanalista. De modo que a passagem de psicanalisante a psicanalista, inerente ao ato do psicanalista, herdou as formulaçóes anteriores destinadas ao desejo do psicanalista. $\mathrm{O}$ ato do psicanalista mostrou-se, destarte, ser uma versão ampliada do desejo do psicanalista.

O desejo do psicanalista é, dessa forma, o que opera na psicanálise para além da terapêutica, para além da transferência e para muito além da identificação, compondo a formação do psicanalista, principalmente em sua vertente intensiva (Lacan, 1967/2003b).

Aqui é possível concluir que tal formação passa, necessariamente, pelo engano do sujeito suposto saber, verdadeiro pivô da transferência, e que, todavia, culmina no desejo do psicanalista. Da transferência ao desejo do psicanalista é então o percurso por meio do qual Lacan pensa o final de análise, com a consequente produção de um psicanalista. E deve-se destacar sua advertência de que o psicanalista deve se haver, no final, com a falta de essência que caracteriza o objeto $a$ e, por consequência, o seu ato $(a \rightarrow B)$.

É nessa direção que Lacan (1966/1998) observou que não se trata de conselho técnico, mas de abertura para a questão do desejo do psicanalista, que este deve evitar os escolhos da transferência no que ela tem de interminável. Pois qualquer

vacilação calculada da "neutralidade do analista" pode valer, para uma histérica, mais do que todas as interpretaçôes, com o risco de transtorno enlouquecido que disso pode resultar. Desde, é claro, que esse transtorno enlouquecido não acarrete o rompimento e que a sequência convença ao sujeito de que o desejo do analista náo teve nada a ver com isso. Esta observação não constitui, é claro, um conselho técnico, mas é uma visão aberta para a questáo do desejo do analista, para aqueles que de outro modo não poderiam ter ideia dela: como deve $o$ analista preservar para $o$ outro a dimensão imaginária de sua não-dominação, de sua imperfeiçẫo necessária, eis o que é táo importante estabelecer quanto o fornecimento, nele voluntário, de sua inciência quanto a cada sujeito que vai procurá-lo em análise, de sua ignorância sempre renovada de que alguns deles constitua um caso (Lacan, 1966/1998, p. 839).

Jamais perder a perspectiva da falta inerente ao sujeito $(S)$, ao desejo (objeto $a)$ e ao Outro $[\mathrm{S}(\mathbb{A})$ ] é, portanto, a posição que Lacan adota abertamente no 
que diz respeito à direção do tratamento, ou seja, à ética na psicanálise - e seu operador elementar aqui destacado: o desejo do psicanalista. E essa direçáo é nitidamente marcada pela posição em que o psicanalista se coloca: destituído como sujeito e, por isso mesmo, aberto para ser tomado como objeto causa do desejo.

Estar aberto para ser tomado como objeto causa do desejo pressupóe, entretanto, a existência da transferência (e de seu elemento pivô, o sujeito suposto saber) articulada ao sintoma como fonte de sofrimento e de questionamento (enigma). Isso porque, quando o sintoma ganha estatuto de enigma - fato que se conhece por sintoma analítico - ele certamente já está sob a ação do sujeito suposto saber, deslocado ou não para o psicanalista.

\section{Para finalizar}

Recapitulando, o desejo do psicanalista surgiu inicialmente no ensino de Lacan para fazer contraponto ao desejo do Outro. Contudo, como pano de fundo, já havia a preocupação com o trabalho do psicanalista, com a resposta que se espera dele diante da emergência das demandas de amor do psicanalisante. Posteriormente, tal desejo é tido como táo vazio de essência quanto o objeto $a$ e, por isso mesmo, sem identidade/identificação possível. Sua função clínica elementar diz ainda respeito à presentificaçáo do objeto $a$ no campo do Outro, daí sua proximidade com a angústia, localizada entre o gozo e o desejo (Lacan, 1962-1963/2005).

Verifica-se, ainda, que Lacan, além de formalizar o desejo do psicanalista para fazer oposição ao modelo de cura-padrão promovido pela IPA, também buscou com essa expressão fazer frente ao conceito de contratransferência utilizado pelos kleinianos (Pelot, 1979/1987). Segundo a abordagem kleiniana, a contratransferência se manifestaria por meio de sinais reativos ao discurso do sujeito em análise, sinais esses que se manifestariam no inconsciente do psicanalista e que deveriam, a partir daí, ser considerados como guias do tratamento. Servir-se desses sinais para intervir clinicamente, ao contrário de negá-los, era, então, o lema dessa orientação (Klein, 1952/1982).

Lacan não nega a importância da contratransferência no tratamento psicanalítico, contudo o que ele propóe com a expressão desejo do psicanalista é, nos mesmos moldes do objeto $a$, a ênfase no esvaziamento de qualquer substância. Propóe, então, abordá-lo como o lugar em que a falta de qualquer substância identificatória intervém sobre o sujeito $(a \rightarrow \$)$.

Ainda a título de conclusão, parece apropriado utilizar um capítulo que se encontra no Seminário 8 (Lacan, 1960-1961/1992) para finalizar o percurso feito 
até aqui sobre "o desejo do psicanalista no ensino lacaniano". Em sua "Crítica da contratransferência”, Lacan (1960-1961/1992, p.182) ensina que o psicanalista bem analisado não está fora do alcance das paixôes e se pergunta por que um psicanalista, a pretexto de ser bem analisado, seria insensível ao surgimento de pensamento hostil, ao movimento de amor e ódio pelo paciente. Considera que isso não o desqualifica em sua função e assegura que, quanto melhor analisado, mais será possível que o psicanalista "seja francamente amoroso, ou francamente tomado por um estado de aversão, de repulsa, dos modos mais elementares da relação de corpos entre si, com referência ao seu parceiro" (Lacan, 1960-1961/1992, p. 186). Tem ciência de que diz algo forte, mas não se detém frente ao fato de que a apatia analítica, uma exigência que era apontada para a prática, deveria se enraizar em outra parte e náo no campo de suas ideias.

Mas, se o analista é até mais propício a experimentar as paixóes, e se ele não realiza uma descarga imaginária total na análise, se não chega "às vias de fato com seu paciente, tomando-o nos braços ou atirando-o pela janela, é porque é possuído por um desejo mais forte" (Lacan, 1960-1961/1992, p. 187). Desejo que resulta de mutação na economia do desejo de um analista e que nos mostra os efeitos do tratamento sobre seu campo (do desejo), observa Lacan no momento em que enfatiza a transferência e não a contratransferência. Depois de explorar um caso de contratransferência apresentado por Roger Money-Kyrle, psicanalista do círculo kleiniano, Lacan comenta: "Não estou ratificando a propriedade dessa maneira de proceder" (Lacan, 1960-1961/1992, p.194). Do que se trata, para ele, em todo caso, é de um efeito irredutível da situação de transferência, simplesmente, por si mesma. Não haveria razáo para qualificá-la de outro modo.

O fato de haver transferência implica o psicanalista na posiçáo de

ser aquele que contém o agalma, o objeto fundamental de que se trata na análise do sujeito, como ligado, condicionado por essa relação de vacilação do sujeito que caracterizamos como o que constitui a fantasia fundamental, como o que instaura o lugar onde o sujeito pode se fixar como desejo (Lacan, 1960-1961/1992, p. 194).

Em posição daquele que póe em dúvida o que compreende, o psicanalista procura alcançar justamente o que, em princípio, não compreende. Entretanto, "é somente na medida em que ele sabe o que é o desejo, mas não sabe o que esse sujeito, com quem embarcou na aventura analítica, deseja, que ele está em posição de ter em si, deste desejo, o objeto" (Lacan, 1960-1961/1992, p. 194). Daí a responsabilidade do desejo do psicanalista. 
As referências ao desejo do psicanalista são abundantes no ensino de Lacan, como é possível constatar na referência acima. Elas ocorrem principalmente por volta de $1967^{3}$, período esse em que Lacan esteve envolvido com a criação e manutençáo de sua Escola, a Escola Freudiana de Paris, e com uma nova proposta de formação e de autorização do psicanalista (Lacan, 1968/2003b). Para tal, a experiência de passagem da situação de psicanalisante a psicanalista seria determinante e deveria ser abordada em sua Escola recém-criada. Se a psicanálise pura é a psicanálise didática, caberia investigar, nessa passagem, o surgimento do des-ser do analista a partir do que aí foi vivido, em sua própria análise, como destituição subjetiva. Para isso, Lacan inventou o dispositivo do passe como meio de verificação e de teorização do que foi o final de uma análise e sua ligação com o desejo do psicanalista $[\mathrm{S}(\mathbb{A})]$.

A formação de analistas, a partir da perspectiva da Escola de Lacan, exigia, portanto, novos modos de operar a psicanálise, principalmente a partir de uma política que fosse condizente aos princípios éticos e conceitos fundamentais da psicanálise.

Por tudo isso, ao implicarmos o desejo do psicanalista na transferência, o que daí resultou foi o fato de ela predestinar-se, por isso mesmo, à destituiçáo destituição essa assinalada como efeito indelével da política da falta-a-ser levada a sério pelo psicanalista.

\section{Referências}

Albuquerque, F. (2012). Desejo do analista: do horror ao saber ao amor ao saber. Recuperado em 12 de março, 2012, de http://flaviaalbuquerque.com.br/textos/HORROR\%20 AO\%20SABER\%20AO\%20AMOR\%20AO\%20SABER.doc.

Andrade Júnior, M. (2008). Ética da psicanálise e desejo do analista: bases conceituais do desejo do analista na ética do Seminário VII de Lacan. (Dissertação de Mestrado. Programa de Pós-Graduação em Psicologia da Faculdade de Filosofia e Ciências Humanas, Universidade Federal de Minas Gerais, Belo Horizonte, MG)

Castro, J. E. (2006). Consequências éticas da teoria lacaniana dos discursos no ensino da psicanálise. (Tese de Doutorado. Programa de Pós-Graduaçáo em Teoria Psicanalítica, Universidade Federal do Rio de Janeiro, Rio de Janeiro, RJ)

Cottet, S. (1990). Freud e o desejo do psicanalista. Rio de Janeiro: Jorge Zahar. (Trabalho original publicado em 1982)

Harari, A. (2012). Ponto de emergência do desejo do analista? Opção Lacaniana online nova série, 1(3). Recuperado em 23 de novembro, 2012, de http://www.opcaolacaniana.com.br/ nranterior/numero3/texto5.html 
Klein, M. (1982). As origens da transferência. São Paulo: Ática. (Trabalho original publicado em 1952)

Lacan, J. ([s.d.]). O seminário, livro 6: o desejo e sua interpretação. Edição Eletrônica em CD-ROM dos Seminários e Escritos de Jacques Lacan [CD-ROM]. Buenos Aires: Escola Freudiana de Buenos Aires. (Seminário original de 1958-1959)

Lacan, J. ([s.d.]). O seminário, livro 9: a identificação. Edição Eletrônica em CD-ROM dos Seminários e Escritos de Jacques Lacan [CD-ROM]. Buenos Aires: Escola Freudiana de Buenos Aires. (Seminário original de 1961-1962)

Lacan, J. ([s.d.]). O seminário, livro 12: problemas cruciais para a psicanálise. Edição Eletrônica em CD-ROM dos Seminários e Escritos de Jacques Lacan [CD-ROM]. Buenos Aires: Escola Freudiana de Buenos Aires. (Seminário original de 1964-1965)

Lacan, J. (1979). O seminário, livro 11: os quatro conceitos fundamentais da psicanálise. Rio de Janeiro: Jorge Zahar. (Seminário original de 1964)

Lacan, J. (1988). O seminário, livro 7: a ética da psicanálise. Rio de Janeiro: Jorge Zahar. (Seminário original de 1959-1960)

Lacan, J. (1992). O seminário, livro 8: a transferência. Rio de Janeiro: Jorge Zahar. (Seminário original de 1960-1961)

Lacan, J. (1992). O seminário livro 17: o avesso da psicanálise. Rio de Janeiro: Jorge Zahar. (Seminário original de 1969-1970)

Lacan, J. (1995). O seminário, livro 15: l'acte psychanalytique. Edição em francês: Escola Freudiana de Paris. (Seminário original de 1967-1968)

Lacan, J. (1998). Intervenção sobre a transferência. In J. Lacan, Escritos. Rio de Janeiro: Jorge Zahar. (Trabalho original publicado em 1952)

Lacan, J. (1998). A direção do tratamento e os princípios de seu poder. In J. Lacan, Escritos. Rio de Janeiro: Jorge Zahar. (Trabalho original publicado em 1961)

Lacan, J. (1998). Subversão do sujeito e dialética do desejo no inconsciente freudiano. In J. Lacan, Escritos. Rio de Janeiro: Jorge Zahar. (Trabalho original publicado em 1966)

Lacan, J. (1998). Do “Trieb” de Freud e do desejo do psicanalista. In J. Lacan, Escritos. Rio de Janeiro: Jorge Zahar. (Trabalho original publicado em 1964)

Lacan, J. (2003a). O engano do sujeito suposto saber. In J. Lacan, Outros escritos. Rio de Janeiro: Jorge Zahar. (Trabalho original publicado em 1968)

Lacan, J. (2003b). Proposição de 9 de outubro de 1967 sobre o psicanalista da Escola. In J. Lacan, Outros escritos. Rio de Janeiro: Jorge Zahar. (Trabalho original publicado em 1968)

Lacan, J. (2005). O seminário, livro 10: a angústia. Rio de Janeiro: Jorge Zahar. (Seminário original de 1962-1963)

Pelot, J.-M. (1987). Melanie Klein: estudos. São Paulo: Perspectiva. (Trabalho original publicado em 1979) 


\section{Notas}

${ }^{1}$ Os serviços dos bens mencionados por Lacan são: os bens privados, os bens de família, os bens da casa, os bens do ofício, os bens da profissão e os bens da Cidade.

${ }^{2}$ Lembremo-nos aqui da máxima presente nesse mesmo Seminário: sujeito e ato se excluem, ou seja, onde há ato analítico não há sujeito e vice-versa. Durante a finalização de uma análise haveria então - mais do que a exclusão lógica entre sujeito e ato - a subordinação do primeiro termo ao segundo, o que nos faz formulá-lo aqui como sujeito ao ato.

${ }^{3} \mathrm{Na}$ verdade entre os anos de 1959 e 1972.

Recebido em 31 de maio de 2012 Aceito para publicação em 08 de agosto de 2012 